\title{
GEOCHRONOLOGY (U-PB/PB-PB) AND ISOTOPIC SIGNATURE (RB-SR/SM-ND) OF THE PALEOPROTEROZOIC GUANAMBI BATHOLITH, SOUTHWEST BAHIA STATE (NE BRAZIL)
}

\author{
MARIA DE LOURDES DA SILVA ROSA ${ }^{1}$, HERBET CONCEICAO ${ }^{1}$, FELIX OBERLI' $^{2}$, MARTIN MEIER ${ }^{2}$, HERVE MARTIN ${ }^{3}$, \\ MOACIR JOSE BUENANO MACAMBIRA ${ }^{4}$, EMERSON BARRETO DOS SANTOS ${ }^{1}$, MARCIO MATTOS PAIM ${ }^{1}$, GERALDO \\ AUGUSTO DA SILVA LEAHY ${ }^{1}$ AND LUIZ ROGERIO BASTOS LEAL ${ }^{1}$
}

\begin{abstract}
The Guanambi batholith (GB) is located in south-western Bahia, Brazil, where it forms part of the Urandi-Paratinga mobile belt. The batholith extends over an area of almost $6,000 \mathrm{~km}^{2}$ and is mainly composed of syenites and monzonites, with subordinate granites, mafic syenites and lamprophyric dykes. Two main units can be recognized: the multiple intrusions, being divided into four regions (Paratinga, Laguna, Igapora and Guanambi) and the so-called late-intrusions forming the Cara Suja, Cerafma and Estreito massifs. U-Pb and $\mathrm{Pb}-\mathrm{Pb}$ isotopic data demonstrate that the batholith was emplaced $2.05 \mathrm{Ga}$ ago. GB has (i) highly negative initial $\varepsilon_{\mathrm{Nd}}(-7.4$ to -10.6$)$, pointing to an enriched source, and (ii) Sr initial ratios between 0.704 and 0.707 . Both chemical and isotopic signatures suggest that GB formed by fractional crystallization of a lamprophyric magma derived from a Paleoproterozoic enriched mantle source.
\end{abstract}

Keywords: Guanambi batholith, geochronology, enriched mantle, syenites

INTRODUCTION Syenitic magmatism, widespread in Bahia State (Brazil) during Precambrian times, can be divided into two age groups: Transamazonian (1.8-2.1 Ga) and Brasiliano (0.45-0.70 Ga). Ca. 90\% of the syenite massifs in Bahia belong to the Transamazonian group. These silica-saturated rocks form large batholiths, which intrude the Paleoproterozoic mobile belts representing part of the basement of the Sao Francisco Craton. $<10 \%$ of the syenites belong to the Brasiliano group, represented by small ring complexes dominated by plutonic silica-undersaturated rocks.

There are two Paleoproterozoic mobile belts in Bahia: i) the Urandi-Paratinga mobile belt (UPMB) and ii) the Salvador-Curaçá mobile belt (SCMB) located in the western and eastern parts of the state, respectively. Both belts are characterized by the emplacement of alkali-syenitic, potassic to ultrapotassic rocks during late-stage stabilization (Conceição 1993). The syenites of the SCMB are concentrated in four separate massifs, being emplaced as tabular bodies and displaying gneissic texture, whereas in the UPMB, the syenites form a large, $6,000 \mathrm{~km}^{2}$ sized, single batholith, the Guanambi batholith (GB), which is related to a pull-apart system and shows exclusively magmatic textures. In this paper, we focus on the geochronology and isotopic signature of the Guanambi Batholith, which represents the largest association of potassic-ultrapotassic syenitic and monzonitic rocks in the São Francisco Craton.

GEOLOGICAL SETTING The north-south trending GB has a sigmoidal shape and is ca. $220 \mathrm{~km}$ long and between 15 to $60 \mathrm{~km}$ wide (Fig. 1). It is located in the southern part of the Sao Francisco Craton in the Urandi-Paratinga mobile belt (UPMB). The belt consists of three units (Fig. 1): (i) the Santa Izabel Complex at its eastern border, represented by gneisses, migmatites and granulites with $\mathrm{U}-\mathrm{Pb}$ zircon ages of ca. $3.35 \pm 0.29$ Ga (Rosa 1999); (ii) volcano-sedimentary sequences, composed of quartzites, iron formations, pillow lavas and marbles metamorphosed under amphibolite facies, and (iii) the GB intrusives, which occur in the central part of the belt.

The batholith is mainly composed of syenites and monzogranites, with subordinate granites and mafic syenites. Lamprophyric dykes (minettes) also occur (Paim et al. 1999). Two main domains can be distinguished (i) multiple intrusions (about $90 \%$ of the batholith), and (ii) the so-called late intrusions, which comprise the three massifs Cara Suja $\left(200 \mathrm{~km}^{2}\right)$, Cerafma $\left(120 \mathrm{~km}^{2}\right)$ and Estreito $\left(290 \mathrm{~km}^{2}\right)$. Based on structural data, Rosa et al. (1996) propose that the GB was emplaced into a pull-apart system.

PETROGRAPHY AND GEOCHEMISTRY The multiple and late intrusions are mainly composed of leucocratic and porphyritic rocks and display similar mineralogy and texture. The magmatic crystallization sequence is: accessory minerals (zircon, apatite, monazite, opaque minerals) $\Rightarrow$ diopside $\Rightarrow$ plagioclase $\Rightarrow$ alkali feldspar
$\Rightarrow$ (amphibole, mica, perthitic feldspar) $\Rightarrow$ quartz $\Rightarrow$ titanite. Magmatic crystallization has occurred in two stages: a first stage at low $f \mathrm{O}_{2}$, high $\mathrm{P}_{\mathrm{H} 2 \mathrm{O}}$, and transsolvus conditions, accompanied by accessory mineral, feldspar and clinopyroxene crystallization, was followed by a second stage at hypersolvus conditions, characterized by amphibole and feldspar crystallization. The titanite + magnetite + quartz association present at the second stage indicates highyO. between the $\mathrm{NiNiO}$ and HM buffers.

Geochemical data show that the GB rocks are Si-saturated to oversaturated, alkalic and metaluminous. The $\mathrm{K}_{2} \mathrm{O} / \mathrm{Na}_{2} \mathrm{O}$ ratio is always greater than unity, being higher in the mafic members, which can be classified as ultrapotassic (Foley et al. 1987). Ba $(<8,000 \mathrm{ppm})$ $\mathrm{Sr}(<6,000 \mathrm{ppm})$ and $\mathrm{Rb}(<940 \mathrm{ppm})$ are strongly enriched in these rocks. $\mathrm{Cr}$ (50 to $700 \mathrm{ppm}), \mathrm{Ni}$ (80 to $270 \mathrm{ppm})$ and $\mathrm{Mg \#} \mathrm{(0.20} \mathrm{to} 0.77)$ are relatively high for common syenitic rocks. Chondrite-normalized REE patterns show strongly fractionated LREE with none or only small negative Eu anomaly. The tectonic discrimination diagrams of the GB rocks as well as their geological context point to a subductionrelated and post-collisional setting (Rosa 1999).

U-Pb AND Pb-Pb ZIRCON GEOCHRONOLOGY The U-Pb single zircon analyses were performed at the Swiss Federal Institute of Technology - ETH (Zurich) laboratories (Rosa 1999). The single zircon evaporation $\mathrm{Pb}-\mathrm{Pb}$ analyses were carried out by Sachet and Macambira (1998) at the Laboratory for Isotope Geology (Para-Iso), Para Federal University, Brazil. The U decay constants are those recommended by IUGS (Steiger and jäger 1977), and errors are given at the $95 \%$ confidence level. The analyzed zircon populations were dominated by brown to light-brown crystals, most of them showing cracks and abundant inclusions.

Single-zircon $\mathrm{U}-\mathrm{Pb}$ results by isotope dilution techniques The results of six zircon analyses from a sample representative of the multiple intrusions in the Guanambi Region is shown in Fig. 2A. The discordant data points plot on or near a discordia line defining an upper concordia intercept at $2054+8 /-6 \mathrm{Ma}$ $(\mathrm{MSWD}=7.2$, ext. error). Four zircons each were analyzed for three representative members of the late intrusions (Fig. 2A). Three out of four discordant data points from the Cara Suja massif give an upper intercept age of $2053 \pm 3 \mathrm{Ma}$ (MSWD= 4.6, int. error), with the fourth data point being displaced to the left of the line. The results for the Cerafma massif show a tight concordant cluster yielding a ${ }^{207} \mathrm{~Pb} / 206 \mathrm{~Pb}$ age of $2050.4 \pm 1.4 \mathrm{Ma}$ (MSWD=0.67, int. error). The ${ }^{207} \mathrm{~Pb} /{ }^{206} \mathrm{~Pb}$ ages obtained for the four concordant to near concordant data points from the Estreito massif display scatter in excess of their analytical uncertainties. Interpreting the oldest result $(2061 \pm 5 \mathrm{Ma})$ as potentially being affected by inheritance, the remaining three grains give a weighted mean ${ }^{207} \mathrm{~Pb} /{ }^{206} \mathrm{~Pb}$ age of $2054 \pm 3 \mathrm{Ma}(\mathrm{MSWD}=1.64$,

1 - Grupo de Petrologia Aplicada - CPGG - Dep. de Geoquímica - IGEO - UFBA, Rua Caetano Moura, 123. CEP:40.210-340, Salvador-Bahia, Brasil (e-mail: lourdes@ cpgg. ufba.br)

2 - Swiss Federal Institute of Technology (ETH), Zurich, Switzerland

3 - UMR 6524 CNRS, Universite Blaise Pascal, Clermont-Ferrand, France

4 - Laboratorio de Geologia Isotopica (Para-Iso), Universidade Federal do Para-Belem, Brasil 

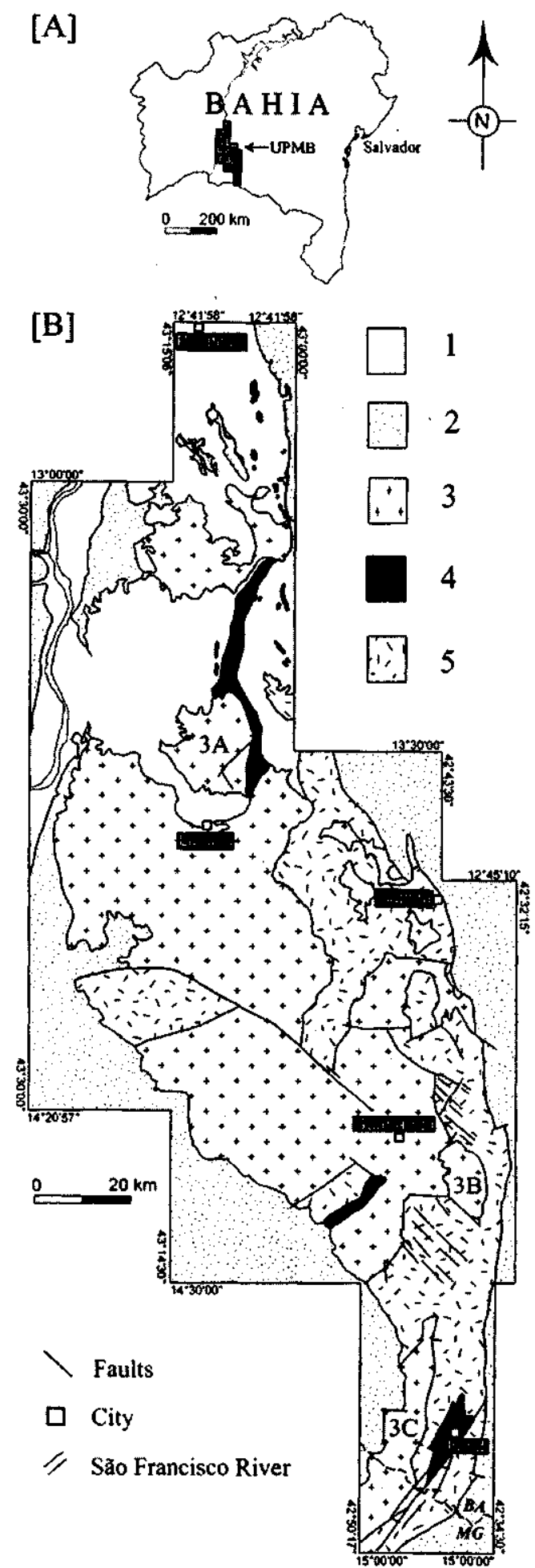

Figure I - (A) - Location map of Urandi-Paratinga mobile belt (UPMB) in Bahia. (B) - Simplified geological map of the UPMB. Phanerozoic Cover (1), Meso-Neoproterozoic Covers (2), Guanambi Batholith (3), Cara Suja Massif (3A), Ceraima Massif (3B), Estreito Massif (3C), Volcano-Sedimentary Sequence (4), Santa Izabel Complex (5), Bahia (BA), Minas Gerais (MG).

int. error), similar to the age of the other two massifs. The combined results suggest an age of 2.050-2.055 Ga for the crystallization of the GB (2.05-2.06 Ga, if the upper error boundary of the zircons from the Guanambi Region is taken into account). The somewhat disturbed data patterns obtained for three out of the four zircon populations analyzed do not permit to resolve potential time differences for the emplacement of the multiple and late intrusions.
Single-zircon $\mathbf{P b}$ evaporation dating Four crystals from a sample representative of the multiple intrusions (Guanambi Region) analyzed by the stepwise $\mathrm{Pb}$ evaporation technique (Kober 1986) yield a mean ${ }^{207} \mathrm{~Pb} /{ }^{206} \mathrm{~Pb}$ age of $2046 \pm 10 \mathrm{Ma}$ (Rosa 1999). Similar ages were obtained for members of the late intrusions, where one zircon from the Ceraima massif shows an age of $2049 \pm 2$ Ma and four zircons from the Estreito massif have a mean age of $2041 \pm 2$ Ma (Rosa 1999). Apart from the younger age obtained for the latter, the results are in support of the $-2.05 \mathrm{Ga}$ crystallization ages obtained by $\mathrm{U}-\mathrm{Pb}$ techniques for the GB lithologies.

\section{Rb-Sr AND Sm-Nd ISOTOPIC SIGNATURES Rb, $\mathrm{Sr}, \mathrm{Sm}$} and $\mathrm{Nd}$ whole-rock contents and $\mathrm{Sr}$ and $\mathrm{Nd}$ isotopic compositions were measured by isotope dilution techniques at the Universite Blaise Pascal (Clermont-Ferrand) using a Cameca THN-206 mass spectrometer (Rosa 1999). Uncertainties for ${ }^{147} \mathrm{Sm} /{ }^{144} \mathrm{Nd}$ and ${ }^{87} \mathrm{Rb} /$ ${ }^{80} \mathrm{Sr}$ are $0.5 \%$ and $2 \%$, respectively. Initial ${ }^{87} \mathrm{Sr} /{ }^{86} \mathrm{Sr},{ }^{143} \mathrm{Nd} /{ }^{144} \mathrm{Nd}$ and $\mathrm{e}_{\mathrm{Nd}}$ were computed adopting an age of $2.05 \mathrm{Ga}$ based on the U-Pb resu]ts.

Initial ${ }^{87} \mathrm{Sr} /{ }^{86} \mathrm{Sr}$ in the Guanambi Region ranges from 0.705 to 0.707 . Similar values of $0.704-0.707$ obtained for the late intrusions (Tab. 1) are indicative of a common source. The $\varepsilon_{N d}$ values of the GB rocks are strongly negative (-7.4 to -10.6) and imply a LREE-enriched source.

In the ${ }^{87} \mathrm{Sr} /{ }^{86} \mathrm{Sr}$ vs $\varepsilon_{\mathrm{Nd}}$ diagram (Fig. 2B), the GB rocks group tightly in the enriched-source sector. Two contrasting explanations must be considered for this particular pattern: (i) crustal contamination of the GB magma by assimilation of basement rocks, or (ii), derivation from an enriched mantle source. Absence of correlation between initial ${ }^{87} \mathrm{Sr} /{ }^{86} \mathrm{Sr}$ and $1 / \mathrm{Sr}$ suggests that crustal contamination was not important. Similarly, there is no correlation between ${ }^{87} \mathrm{Sr} /{ }^{86} \mathrm{Sr}$ and $\mathrm{SiO}_{2}$ or $\mathrm{Al}_{2} \mathrm{O}_{3}$. High $\mathrm{Mg} \#, \mathrm{Ni}$, and $\mathrm{Cr}$ as well as the ubiquitous presence of lamprophyric rocks argue against significant crustal input. We therefore conclude that the chemical and isotopic signature of the GB is inherited from an enriched mantle source.

\section{DISCUSSION AND CONCLUSIONS}

The $2.05 \mathrm{Ga}$ crystallization age of the GB rocks marks the last magmatic activity in the UPMB region. It further documents a time gap of $0.5 \mathrm{Ga}$ between the emplacement of the syenites of the UPMB and those of the SCMB located in the eastern part of Bahia, which gave a U-Pb zircon age of 2.1 Ga (Conceição 1993). The time interval may reflect changes in the structural regimes of the Paleoproterozoic belts, because, in contrast with the GB rocks, the SCMB syenites are strongly deformed, elongated in a N-S direction and are interpreted as dikes emplaced in a syn-collisional system (Conceição et al. 1997), while the GB has intruded a post-collisional environment (Rosa et al. 1996).

Several lines of evidence suggest that an enriched mantle source provides the best explanation for the chemical and isotopic signature of the GB rocks. The existence of a Paleoproterozoic enriched mantle in Bahia has already been suggested by Conceição et al. (1997) in order to explain the genesis of the Paleoproterozoic syenites of the SCMB. Similarly, Ferreira et al. (1997) and Guimarães and da Silva Filho (1998) suggest a metasomatized mantle source for the Neoproterozoic syenitic (NS) Triunfo and Bom Jardim plutons located in the Borborema Province (also in northeastern Brazil). The initial ${ }^{87} \mathrm{Sr}{ }^{86} \mathrm{Sr}$ ratios of the SCMB and of the Bom Jardim syenites are similar those of the GB rocks (Fig. 2B), whereas $\varepsilon_{\mathrm{Nd}}$ is more positive (0 to $-6)$ in the SCMB syenites and more negative $(-10$ to -18$)$ in the NS.

Partial melting of an enriched mantle as a source for potassic magmas has been put forward by Wyllie \& Sekine (1982). According to these authors, mantle metassomatism leading to growth of phlogopite can occur in the root of subduction zones $\left({ }^{3} 100 \mathrm{~km}\right)$ as a result of interaction between cool hydrous siliceous magmas rising from the subducted oceanic crust and the hotter overlying mantle. The nature and composition of the fluids originating from a subduction process are rather complex topics (Wyllie and Sekine 1982, Conticelli and Peccerillo 1992, Ferreira et al. 1997). There is, however, some general agreement that the fluids are generated by selective dehydration of the subducting oceanic crust, especially of serpentine and pelagic sediments (clay minerals + carbonates $>>$ pelites).

Based on Nd model ages, Ferreira et al. (1997) and Guimaraes and Da Silva Filho (1998) have argued that mantle metassomatism in the Boborema Province has occurred during the Paleoproterozoic (2.4-2.0 

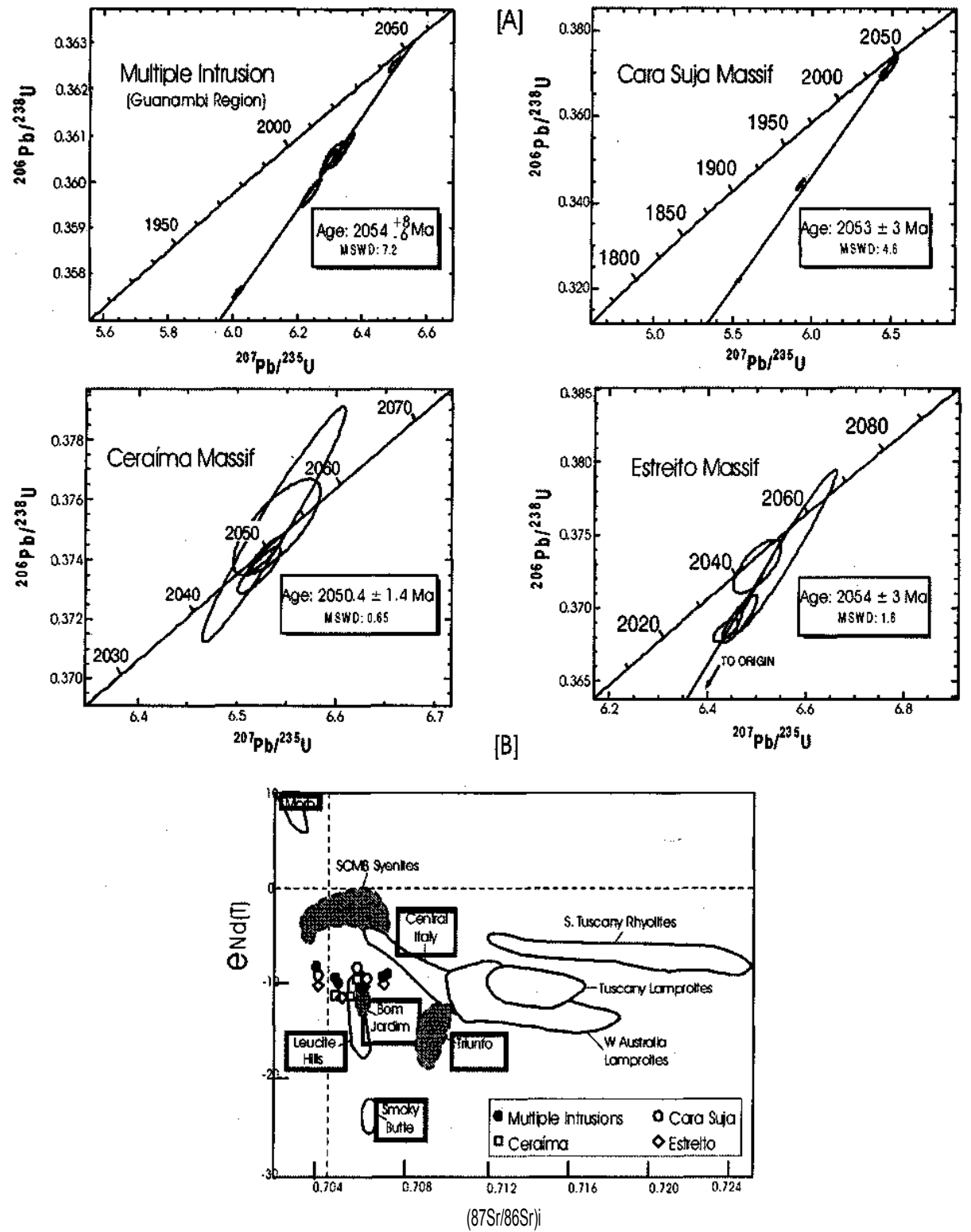

Figure 2 -(A) - U-Pb concordia diagrams for the Guanambi batholith. (B) - Initial ${ }^{87}{ }^{8 r}{ }^{86} \mathrm{Sr} v \mathrm{v} e_{N d}$ for the Guanambi batholith compared to other occurrences ofpotassic and ultrapotassic rocks. Data are from Conticelli and Peccerillo (1992), Conceicao (1997), Ferreira et al. (1997), Guimaraes and Da Silva Filho (1998).

Table 1 - Rb-Sr and Sm-Nd isotopic data for the Guanambi batholith. Multiple intrusions (MI), Cara Suja (CS), Ceraima (CE), Estreito (ES).

\begin{tabular}{|c|c|c|c|c|c|c|c|c|c|c|}
\hline \begin{tabular}{|l|} 
Sample \\
\end{tabular} & Locality & $\begin{array}{c}\mathbf{R b} \\
\text { (ppm) }\end{array}$ & $\begin{array}{c}\mathbf{S r} \\
\text { (ppm) }\end{array}$ & ${ }^{87} \mathrm{Rb} /{ }^{86} \mathrm{Sr}$ & ${ }^{87} \mathrm{Sr} /{ }^{86} \mathrm{Sr}$ & $\left({ }^{87} \mathrm{Sr} /{ }^{\beta 6} \mathrm{Sr}\right)_{\mathrm{i}}$ & $\begin{array}{c}\mathrm{Sm} \\
(\mathrm{ppm})\end{array}$ & $\begin{array}{c}\mathbf{N d} \\
(\mathbf{p p m})\end{array}$ & ${ }^{147} \mathbf{S m} \mathbf{1}^{144} \mathrm{Nd}$ & $\int^{143} \mathrm{Nd} / /^{149} \mathrm{Nd}$ \\
\hline 996 & MI & 127 & 1009 & 0.3642 & 0.716735 & 0.7060 & 24.60 & 186.2 & 0.0799 & 0.510591 \\
\hline 1002 & MI & 135 & 883 & 0.4447 & 0.719331 & 0.7062 & 27.03 & 177.4 & 0.0922 & 0.510725 \\
\hline 1008 & MI & 229 & 656 & 1.0112 & 0.736326 & 0.7065 & 24.20 & 168.6 & 0.0868 & 0.510686 \\
\hline 1128 & MI & 146 & 985 & 0.4287 & 0.719936 & 0.7073 & 26.07 & 172.8 & 0.0913 & 0.510778 \\
\hline 1139 & MI & 158 & 726 & 0.6307 & 0.724695 & 0.7061 & 25.99 & 168.2 & 0.0935 & 0.510781 \\
\hline 1141 & MI & 236 & 1259 & 0.5414 & 0.723446 & 0.7075 & 21.95 & 141.4 & 0.0939 & 0.510831 \\
\hline 1216 & MI & 191 & 794 & 0.6970 & 0.725691 & 0.7051 & 19.58 & 133.8 & 0.0885 & 0.510698 \\
\hline 1146 & MI & 193 & 385 & $1.451]$ & 0.746839 & 0.7040 & 21.58 & 188.0 & 0.0694 & 0.510542 \\
\hline 1160 & MI & 271 & 1236 & 0.6337 & 0.724054 & 0.7053 & 17.83 & 107.3 & 0.1005 & 0.510906 \\
\hline 974 & $\overline{C S}$ & 340 & 1159 & 0.8553 & 0.72939 & 0.7060 & 25.31 & 161.9 & 0.0946 & 0.510877 \\
\hline 982 & $\mathrm{CS}$ & 330 & 454 & 2.1007 & 0.76861 & 0.7041 & 8.04 & 54.1 & 0.0898 & 0.510737 \\
\hline 983 & $\mathrm{CS}$ & 261 & 560 & 1.3463 & 0.74581 & 0.7066 & 24.79 & 186.1 & 0.0806 & 0.510591 \\
\hline 985 & $\mathrm{CE}$ & 188 & 1519 & 0.3576 & 0.715466 & 0.7049 & 36.30 & 216.3 & 0.1015 & 0.510819 \\
\hline 1170 & $\mathrm{CE}$ & 175 & 6192 & 0.0818 & 0.708121 & 0.7057 & 25.12 & 148.1 & 0.1026 & 0.510847 \\
\hline 1200 & $C E$ & 197 & 1762 & 0.3226 & 0.71525 & 0.7057 & 29.80 & 177.0 & 0.1016 & 0.510846 \\
\hline 1009 & ES & 179 & 1347 & 0.3837 & 0.716717 & 0.7054 & 6.94 & 46.6 & 0.0902 & 0.510659 \\
\hline 1014 & ES & 237 & 1493 & 0.4590 & 0.717659 & 0.7041 & 20.17 & 127.5 & 0.0957 & 0.510762 \\
\hline 1228 & ES & 157 & 477 & 0.9520 & 0.735404 & 0.7073 & 28.53 & 288.4 & 0.0598 & 0.510281 \\
\hline
\end{tabular}


Ga). Similar chemical and isotopic characteristics suggest that this interpretation also applies to the GB rocks, which we view as products of fractional crystallization of a lamprophyric magma generated by melting of a Paleoproterozoic enriched mantle, as indicated by Conceição et al. (1997).

The bulk of evidence available so far suggests that a lithospheric mantle region enriched during a Paleoproterozoic event has repeatedly served, over an extensive time interval of at least $1.5 \mathrm{Ga}$, as a source for alkaline magmatism in northeastern Brazil and in Bahia State. Independent of the tectonic regime, this mantle source has been particularly productive during the Paleoproterozoic in generating the vast volumes of syenitic rocks of the mobile belts.

Acknowledgments This paper was supported by CAPES (Process: BEX 3065/95-13 and BEX 2521/97-4), Companhia Baiana de Pesquisa Mineral (CBPM) and CNPq (Process: 521592/97-6). We thank C.G. Perreira Santos for drafting the map and two anonymous referee of RBG for their suggestions, which improved the manuscript. This is the contribution number 72 of GPA-CPGG-UFBA and is a contribution to IGCP-426.

\section{References}

Conceição H. 1993. Petrology of the syenites from Salvador-Curaçá Mobile Belt (BahiaBrazil): geodynamic sionificance. An. Acad. Bras. Ci., 65(1):17-32.

Conceicao H., Martin H., Rosa M.L.S., Conceição R.V., Sabate P. 1997. Alkali-potassic magmas generated by partial melting of an enriched mantle source: example of the
lower Proterozoic plutonism, State of Bahia, NE Brazil. II ISGAM, Ext. Ahstr., 1 OS109 .

Conticelli S. and Peccerillo A. 1992. Petrology and geochemistry of potassic and ultrapotassic volcanism in central Italy: petrogenesis and inference on the evolution of the mantle sources. Lithos, 28(3-6):221-240.

Ferreira V.P., Sial A.N., Long L.E., Pin C. 1997. Isotopic signature of Neoproterozoic to Cambrian ultrapotassic syenitic magmas, Northeastern Brazil: evidence for an enriched mantle source. International Geology Review, 39:660-669.

Foley S.F., Venturelli G., Green D.H., Toscani L. 1987. The ultrapotassic rocks: characteristics, classification and constraints for petrogenetic models. Earth Sci. Rev., 24:81-134.

Guimaraes I.P. and Da Silva Filho A.F. 1998. Nd- and Sr-isotopic and U-Pb geochronologic constraints for evolution of the shoshonitic Brasiliano Bom Jardim and Toritam Complexes: evidences for a Transamazonian enriched mantle under Borborema Tectonic Province, Brasil. International Geology Review, 40:500-527.

Kober B. 1986. Whole-grain evaporation for ${ }^{207} \mathrm{~Pb} /{ }^{206} \mathrm{~Pb}$-age-investigations on single zircons using a double-filament thermal ion source. Contrib. Mineral. Petrol. 93:482-490

Paim M.M., Rosa M.L.S., Conceição H., Barreto Santos E., Bastos Leal L.R. 1999. Aspectos geoquímicos dos lamprofiros (minettes) associados ao maciço sienítico de Cara Suja - Sudoeste da Bahia. V Congresso de Geoquímica dos Países de Lingua Portuguesa \& VII Congresso Brasileiro de Geoquímica, Porto Seguro-BA, Anais:566-568.
RosaM.L.S. 1999. Geologia, Geocronologia, Mineralogia, Litogeoquimica e Petrologia do Batolito Monzo-Sienítico Guanambi-Urandi (SW-Bahia). Institute de Geociências, Universidade Federal da Bahia, Salvador, Tese de Doutoramento, 186p.

Rosa M.L.S., Conceigao H., Paim M.M., Barreto Santos E., Alves Da Silva EC., Leahy G.A.S., Bastos Leal L.R. 1996 Magmatismo potássico-ultrapotássico pos a tardiorogênico (associado a subducção) no oeste da Bahia: Batólito Monzo-Sienitico de Guanambi-Urandi e os Sienitos de Correntina. Geochim. Brasil., 10(1):027-042.

Sachet C.R. and Macambira M.J.B. 1998. Estudo geocronólogico pelo metodo de evaporação de Pb em zircões do Batolito Guanambi-Urandi - BA. Relatorio Técnico, 8p. (Inédito).

Steiger R.H. and Jager E. 1977. Subcommission on geochronology. Convention on the use of decay constants in geo- and cosmochronology. Earth Planet. Sci. Letters, 36:359362

Wyllie P.J. and Sekine T. 1982. The formation of mantle phlogopite in subduction zone hybridization. Contrib. Mineral. Petrol., 79:375-380. 